\title{
PALEOENVIRONMENTAL CONTROL OF SPECIES DISTRIBUTIONS IN NEOGENE INVERTEBRATE TAXA OF THE DOMINICAN REPUBLIC
}

ANDERSON*, Laurie C., Dept. of Geology and Geophysics, Louisiana State University, Baton Rouge, LA 70803; GEARY, Dana H., Dept. of Geology and Geophysics, University of Wisconsin-Madison, Madison, WI 53706; BUDD, Ann, F., Dept. of Geology, University of Iowa, Iowa City, IA 52242; NEHM, Ross H., Museum of Paleontology and Dept of Integrative Biology, University of California, Berkeley, CA 94720; JOHNSON, Kenneth G., Dept. of Geology, University of Iowa, Iowa City, IA 52242; STEMANN, Thomas A., Geologisches Institut, University Bern, Balzerstrasse 1, CH-3012 Bern, Switzerland.

Neogene deposits of the northern Dominican Republic contain a diverse fossil assemblage that is especially rich in corals and mollusks. To see if faunal change was concordant or discordant within and among taxa and decipher factors controlling distributions, we compared distributions of coral communities, the gastropod families Strombidae and Marginellidae, and the bivalve family Corbulidae. We also incorporated published ranges for the Cardiidae (Vokes, 1989), Cancellariidae (Jung and Petit, 1990), and the columbellid genus Strombina (Jung, 1986).

First and last appearances of individual mollusk species were diachronous among sections. Within the sections, however, first and last appearances of mollusk species tended to coincide. Concordance of species ranges could be caused by unconformities or faults, be an artifact of sampling, or indicate similar responses by species to environmental changes. Neither stratigraphic gaps nor faults appear to correspond to concordant first or last appearances. Although the absence of mollusk taxa generally corresponds to less intense sampling, sampling intensity is highly correlated with the presence of macrofossils and therefore, taxa absence is probably real. First and last appearances do coincide with paleoenvironmental changes such as rapid deepening, introduction of marine conditions, increased intensity of erosional bottom currents, and changes from reefal to sand flat facies.

Comparisons among taxa also helped elucidate other distributions patterns. For instance, comparing coral communities to strombid ranges showed that strombid diversity increased in grass flats (inhabited by free living corals) and reefal deposits, indicating similar ecologic preferences to many modern strombid species. Using the coral fauna to distinguish a grass flat community from other shallow marine facies also helped explain corbulid abundances as environmentally induced, with lower numbers in grass flat deposits.

Simultaneous comparison of species distributions within diverse taxa can help explain the nature of species occurrences. For several mollusk taxa from the Neogene of the Dominican Republic, the general correspondence in distribution patterns across taxa indicates that paleoenvironmental conditions were controlling species distributions.

JUNG, P. 1986. Neogene paleontology in the northern Dominican Republic 2. The genus Strombina (Gastropoda: Columbellidae). Bulletins of American Paleontology, 90: $1-42$.

JUNG, P., and R. E. PETIT. 1990. Neogene paleontology in the northern Dominican Republic 10. The family Cancellariidae (Mollusca: Gastropoda). Bulletins of American Paleontology, 98: 1-144.

VOKES, H. E. 1989. Neogene paleontology in the northern Dominican Republic 9. The family Cardiidae (Mollusca: Bivalvia). Bulletins of American Paleontology, 97: 95$141,154-161$. 